\title{
Až jednou budu učit filosofii na střední škole...
}

\section{When I teach philosophy at a secondary school one day...}

\author{
Gabriela Renátová
}

V současné době, kdy probíhá výuka téměř rok pouze online, se více než kdy jindy stávají čím dál více užitečné a žádoucí mj. také audiovizuální zdroje - edukační podcasty (audio-materiály) a videa. Učitelům mohou usnadnit práci s výkladem látky, studentům mohou předat a doplnit informace mnohdy zábavnější formou, než kterou nabízejí vyučující. Ve své diplomové práci ${ }^{1}$ jsem se věnovala audiovizuálním zdrojům, které se zabývají filosofickými tématy. Podařilo se mi nashromáždit asi padesát kanálů, at už podcastů či videí. Některé materiály byly zdařilejší a obsahově více propracované, jiné byly méně zdařilé. Některé jsou vhodné již pro žáky středních škol, jiné se zabývají tématy vhodnými spíše pro vysokoškolské studenty. Mnoho z nich však stojí za pozornost.

Jestliže mi bude dáno a budu jednou učit na střední škole, audiovizuální zdroje budu ráda využívat. Je však důležité si uvědomit, že ne každý audiovizuální zdroj je vhodným zdrojem pro využití, at už v samotné výuce, nebo k případnému samostudiu. Co se týče výuky filosofie na střední škole, důležitým dokumentem, kterým by se měla řídit každá škola při sestavení svého školního vzdělávacího programu, je Rámcový vzdělávací program (RVP) vydaný Ministerstvem školství, mládeže a tělovýchovy. Jedná se o dokument, který stanovuje určité cíle a očekávání, jež musí dodržet každá škola. RVP předepisuje tzv. klíčové kompetence, kterými by měl každý žák po absolvování

1 RENÁTOVÁ, Gabriela. Využití audiovizuálnich zdrojů ve výuce filozofie. Brno: MU 2020. Dostupné z <https://is.muni.cz/th/iub6q/_MDP_Vyuziti_audiovizualnich_zdroju_pri_vyuce_filozofie_FINAL.pdf $>$. (Pozn. red.) 
studia disponovat, vymezuje také vzdělávací obsah a úroveň, jichž by měl žák dosáhnout. Pracovala jsem zejména s Rámcovým vzdělávacím programem pro gymnázia (RVP G).

Rámcový vzdělávací program pro gymnázia nám předkládá seznam těchto klíčových kompetencí: kompetence k učení, k řešení problémů, kompetence komunikativní, sociální a personální, občanská a kompetence k podnikavosti. ${ }^{2}$ Také edukační audiovizuální materiály mohou podpořit rozvoj zmíněných kompetencí - na základě zhlédnutí/poslechnutí materiálu můžeme diskutovat, pokusit se vyřešit nastíněný problém, spolupracovat apod. Neméně důležité jsou také cíle a očekávané výstupy, které RVP nařizuje. Žák dle RVP G po absolvování filosofie

[...] objasní podstatu filozofického tázání, porovná východiska filozofie, mýtu, náboženství, vědy a umění $\mathrm{k}$ uchopení skutečnosti a člověka; rozliší hlavní filozofické směry, uvede jejich klíčové představitele a porovná řešení základních filozofických otázek v jednotlivých etapách vývoje filozofického myšlení; eticky a věcně správně argumentuje v dialogu a diskusi, uvážlivě a kriticky přistupuje k argumentům druhých lidí, rozpozná nekorektní argumentaci a manipulativní strategie v mezilidské komunikaci; zhodnotí význam vědeckého poznání, techniky a nových technologií pro praktický život i možná rizika jejich zneužití; posuzuje lidské jednání z hlediska etických norem a svědomí jednotlivce, objasní dějinnou proměnlivost základních etických pojmů a norem; rozlišuje významné náboženské systémy, identifikuje projevy náboženské a jiné nesnášenlivosti a rozezná projevy sektářského myšlení. ${ }^{3}$

Z uvedených očekávaných výstupů vyplývá také učivo, které RVP G předepisuje. Jedná se o téma podstaty filosofie, kam spadají základní filosofické otázky, dále vztah filosofie a mýtu, náboženství, vědy a umění. Dále se jedná o filosofii v dějinách, o představení klíčových etap a směrů filosofického myšlení. K učivu probíranému v rámci filosofie řadí RVP G také téma víry v lidském životě, znaky náboženství a náboženské víry, náboženské systémy, církve, ale také sekty. ${ }^{4}$ Tato kritéria, která nám RVP G předkládá, jsem brala v potaz také při výběru vhodných edukačních audiovizuálních materiálů.

2 Více ke klíčovým kompetencím naleznete zde: Rámcový vzdělávací program pro gymnázia. Národni ústav pro vzdèláváni [online, cit. 20. 1. 2013], s. 8. Dostupné z <http:/ / www.nuv.cz/ file/159>.

3 Tamtéž, s. 42-43.

4 Tamtéž. 
Všechny níže zmíněné materiály odpovídají kritériím uvedeným v RVP G, mnohdy je také překračují.

Při samotné výuce bych využívala $\mathrm{z}$ audiovizuálních materiálů zejména videa. Domnívám se totiž, že vizuální stránka spojená s audio-stránkou je pro žáky středních škol atraktivnější a upoutá jejich pozornost a udrží ji déle. Pouštění audio stopy je dle mého názoru stejně efektivní jako samotná přednáška vyučujícího. Jestliže bych chtěla využitím audiovizuálních zdrojů osvěžit samotnou výuku a změnit metodu výuky, pak je dle mého názoru vhodnou volbou právě edukační video. Audio-materiály bych doporučila žákům spíše k nastudování doma. Ohledně jazyka, ve kterém jsou materiály zpracovány: těch v českém jazyce mnoho nenalezneme. Proto uvádím také materiály v anglickém jazyce. Protože filosofie se mnohdy vyučuje v posledním ročníku střední školy, domnívám se, že žáci dosahují dostačující jazykové úrovně, aby porozuměli základním myšlenkám, které nám materiály předkládají. Navíc předpokládám, že po zhlédnutí/poslechnutí materiálu učitel s žáky předložené informace shrne.

$\mathrm{Z}$ mnoha zpracovaných kanálů považuji za nejzdařilejší zejména následující: Katedra filozofie: Didaktická videa KF FF MU, Philosophy Vibe, SRF Kultur: Filosofix (English), TED: Ideas Worth Spreading a Wisecrack: 8-Bit Philosophy. Proč zrovna tyto materiály? Důvody se pokusím představit u každého kanálu níže.

Kanál Katedra filozofie: Didaktická videa $K F F F M U^{5}$ jsem vybrala nejenom proto, že je jako jeden z mála kanálů zaměřených na filosofii v českém jazyce, ale zejména kvůli jeho jedinečnému zpracování, které by mohlo mít u středoškolských žáků velice pozitivní ohlasy. Mnohé informace ve videích nám jsou totiž předkládány nejenom prostřednictvím výkladu Josefa Petrželky, odborného asistenta na Katedře filozofie Filozofické fakulty Masarykovy univerzity, ale také prostřednictvím scének zinscenovaných studenty a vyučujícími Katedry filozofie. Už jen tento způsob zpracování je tak unikátní, že žádný jiný kanál, který jsem zhlédla, touto formou zpracovaný není. Navíc, jak jsem uvedla, jsou materiály v českém jazyce - další plus, které kanál nabízí. Žáci na střední škole jsou dle mého názoru vưči materiálům v anglickém jazyce, potažmo v cizím jazyce obecně, více či méně skeptičtí. Čtení či poslech v cizím jazyce jsou pro ně spíše komplikací, vyžadují po žácích více práce (zejména vyhledávání neznámých slovíček). Pokud jsou k dispozici materiály v českém jazyce, žáci raději sáhnou po nich. Dalším pozitivem je délka materiálů dosahující cca 10 minut. V uplynulých několika měsících kanál

5 Youtube. Katedra filozofie: Didaktická videa KF FF MU [online, cit. 22. 4. 2020], 2019-2020. Dostupné z <https://www.youtube.com/playlist?list=PL9daa1iqZeLieIM5kAs84G9rb9-vxo$\mathrm{XYKc}$. 
předložil také krátké rozhovory zaměřené na klíčové pojmy z filosofie Platóna pod hlavičkou Platónovi na stopě. Opět se jedná o poměrně unikátní formu, kterou nám jsou informace předkládány. Navíc rozhovory trvají cca 5 minut, což je pro žáky střední školy velice atraktivní časový rozsah. Ačkoliv kanál předkládá zatím materiály týkající se vybraných témat z antické a středověké filosofie, věřím, že se můžeme těšit na další materiály z produkce Katedry filozofie FF MU zaměřené i na další témata. Rozhodně bych je uvítala a při výuce na střední škole rozhodně využila. Věřím totiž, že by na ně mohly být velice pozitivní ohlasy, a to právě z důvodů, které jsem uvedla výše. Pro mě osobně se jedná o jeden z nejlepších materiálů zpracovávající filosofická témata na české půdě a v českém jazyce.

Další kanál, který jsem vybrala jako velmi zdařilý, je kanál Philosophy Vibe. ${ }^{6}$ Proč? Opět se jedná o velice atraktivní způsob zpracování filosofických témat, ačkoliv jsou materiály zpracovány v anglickém jazyce. Jde o animovaný rozhovor dvou mužů, kteří diskutují nad danými problémy. Ve videu se občas objeví také fotografie filosofů či jiných objektů a zobrazeny jsou také některé klíčové pojmy. Forma rozhovoru je u filosofických témat dle mého názoru velice přínosná a užitečná. I zde můžeme vidět, že jeden z aktérů přednáší o určitém tématu, zatímco druhý poslouchá a vznáší námitky a dotazy. Tím materiál může pomoci středoškolským žákům ujasnit a uchopit danou problematiku lépe. Zpracování mě zaujalo také proto, že se takové u jiných kanálů neobjevuje. Navíc materiály dosahují délky do 10 minut, což je přijatelný čas, který můžeme ve vyučovací hodině promítnutí videa věnovat a při kterém jsou žáci schopni udržet svoji pozornost. Co se týče témat, kanál se zabývá filosofií Platónovou, Aristotelovou, věnuje se filosofii R. Descarta, existencialismu. Zmiňuje také témata z oblasti etiky a epistemologie - filosofie J. Locka, D. Huma, G. Berkeleyho atd. Jedná se tedy o materiál pro žáky střední školy obsahově vhodný a formou atraktivní.

SRF Kultur: Filosofix (English)7 je kanál, který zpracovává v asi 3minutových videích hlavní myšlenkové experimenty ve filosofii. Jedinečná témata, jedinečné zpracování, krátké trvání - to jsou hlavní faktory, které mě na kanálu zaujaly, a mám za to, že zaujmou i žáky na střední škole. Už při samotném studiu Učitelství základů společenských věd pro střední školy jsem si v hlavě představovala, jak by asi vypadala hodina filosofie na střední škole pod mým

6 Youtube. Philosophy Vibe [online, cit. 14. 5. 2020], 2014-2020. Dostupné z <https://www. youtube.com/channel/UClepFnDpTP3pLKxVsbLNhDA/playlists>.

7 Youtube. SRF Kultur: Filosofix (English) [online, cit. 20. 5. 2020], 2016-2018. Dostupné z <https:// www.youtube.com/playlist?list=PL1NXgjXDUNJk_51d5AJzCj0Rl7avL5E9W>. 
vedením. Utkvěla ve mně myšlenka, že bych rozhodně chtěla učit zábavnou formou a spíše diskusí s žáky. Nechtěla jsem strávit 40 minut přednášením něčeho, co by mohlo zajímat možná tak maximálně čtvrtinu žáků. A právě když jsem se dozvěděla o tomto kanálu a zhlédla jsem zpracované myšlenkové experimenty, říkala jsem si, že to je ono. Filosofii, alespoň některé oblasti filosofie, bych mohla učit tak, že bychom si s žáky představili myšlenkový experiment, na základě kterého bych pak doplnila filosofické pozadí. ${ }^{8}$ Dokonce se mi podařilo jednu takovou hodinu vést. Žáci spolupracovali, byli aktivní a troufám si říct, že i nadšení ze změny a z toho, že viděli, že filosofie je zajímavá. Co se týče formy, myšlenkové experimenty ve videích jsou kreslené, černobílé, doprovázené výkladem v anglickém jazyce. Stejně jako u ostatních kanálů i zde je možné přidat u výkladu automatické titulky, které žákům pomohou k lepšímu porozumění. Navíc předpokládám, že každý učitel po zhlédnutí videa s třídou zopakuje, co se vlastně z videa dozvěděli. Tak by se mělo postupovat dle mého názoru vždy.

TED: Ideas Worth Spreading, ${ }^{9}$ další z velice zdařilých kanálů jak po stránce vizuální, tak i obsahové. Jedná se o neziskovou organizaci, která předkládá materiály, konkrétně videa, v časovém rozmezí od 4 do asi 20 minut. Opět se jedná o materiál v anglickém jazyce. Nemyslím si ale, že by to byl pro žáky střední školy problém, jak jsem uvedla již výše. Tato organizace nabízí materiály jak pod hlavičkou TED Talks, kde jsou zpracovány zejména krátké přednášky vybraných osobností a filosofů, tak pod hlavičkou TED-Ed, kde nalezneme materiály ve formě animovaných videí. Z témat, která kanál předkládá, stojí za zmínku zejména témata z oblasti etiky, epistemologie a z dějin filosofie (od Platóna po S. de Beauvoir). Také u tohoto kanálu mě zaujalo vizuální zpracování u materiálů pod hlavičkou TED-Ed. Formální správnost informací je samožrejmostí. Proč bych využila materiály pod hlavičkou TED Talks? Už jen proto, aby žáci viděli, že lidé za těmi myšlenkami, které v hodinách představujeme, jsou/byli opravdu skuteční. Domnívám se, že zvlášt

8 Také kniha Y. Bossarta zpracovává myšlenkové experimenty a uvádí u nich klíčové filosofické teorie a autory. BOSSART, Yves. Bez dneška by zitra nebylo včera. Praha: Ikar 2016.

9 TED: Ideas Worth Spreading. TED [online, cit. 11. 6. 2020], 2006-2020. Dostupné z <https:// www.ted.com/talks?sort=newest\&topics $\% 5 \mathrm{~B} \% 5 \mathrm{D}=$ philosophy\&language $=\mathrm{en}>$. TEDEd [online, cit. 11. 6. 2020], 2012-2020. Dostupné z <https://ed.ted.com/lessons-?category=philosophy-religion\&direction $=$ desc\&sort=featured-position>. Youtube [online, cit. 11. 6. 2020], 2012-2020. Dostupné z <https://www.youtube.com/user/TEDEducation/-search?query=philosophy>. 
u filosofie je důležité, aby si studenti uvědomili, že ti lidé opravdu existovali a že to, co se jim snažíme předat, jsou skutečné myšlenky skutečných osob.

Posledním kanálem, který zde doporučuji, je Wisecrack: 8-Bit Philosophy. ${ }^{10}$ Informace nám kanál předkládá v asi 3minutových videích, která nás přenášejí do počítačové hry. Prostřednictvím pixelů se dozvídáme klíčové filosofické myšlenky z oblasti etiky, politické filosofie či epistemologie a další mezníky a osobnosti z dějin filosofie od Sókrata po J. Derridu. Ve videu jsou navíc zobrazeny i klíčové pojmy či citáty. Také u tohoto kanálu hraje roli jedinečnost ve zpracování a výběr zpracovaných témat. Anglický jazyk, ve kterém jsou informace předkládány, opět dle mého názoru nebude pro žáky střední školy problém. Základním myšlenkám jistě porozumí.

Důvody, které mě vedly k výběru právě těchto kanálio, jsou jednoduše jedinečné a zajímavé vizuální zpracování, relevantní informace, tematické zaměření a krátká stopáž. Všechny tyto faktory dle mého názoru mohou pomoci k tomu, aby žáky zaujaly a aby udržely jejich pozornost. Věřím, že tak, jako materiály zaujaly mě, zaujmou i další vyučující a zejména žáky středních škol.

\section{Mgr. Gabriela Renátová}

studentka Katedry filozofie, Filozofická fakulta, Masarykova univerzita Arna Nováka 1, 60200 Brno, Česká republika

453302@mail.muni.cz

10 Youtube. Wisecrack: 8-Bit Philosophy [online, cit. 8. 6. 2020], 2014-2016. Dostupné z 〈https://www.youtube.com/playlist?list=PLghL9V9QTN0gCZia2u-YnLxhetxnC_ONF〉.

Toto dílo Ize užít v souladu s licenčními podmínkami Creative Commons BY-NC-ND 4.0 International (https://creativecommons.org/licenses/by-nc-nd/4.0/legalcode). Uvedené se nevztahuje na díla či prvky (např. obrazovou či fotografickou dokumentaci), které jsou v díle užity na základě smluvní licence nebo výjimky či omezení př́slušných práv. 